\title{
Effects of bacterial silage inoculants on whole-crop maize silage fermentation and silage digestibility in rams
}

\author{
B.D. Nkosi ${ }^{1 \#}$, R. Meeske ${ }^{2}$, T. Langa ${ }^{1}$ \& R.S. Thomas ${ }^{1}$ \\ ${ }^{1}$ ARC - LBD : Animal Production Institute, Private Bag x2, Irene, 0062, South Africa. \\ ${ }^{2}$ Western Cape Department of Agriculture, P.O. Box 249, George, 6530, South Africa
Copyright resides with the authors in terms of the Creative Commons Attribution 2.5 South African Licence. See: http://creativecommons.org/licenses/by/2.5/za
Condition of use: The user may copy, distribute, transmit and adapt the work, but must recognise the authors and the South African Journal of Animal Science.

\begin{abstract}
This study evaluated the effects of ensiling whole-crop maize with bacterial inoculants, Lactococcus lactis (LL) and Lactobacillus buchneri (LB), on the fermentation and nutrient digestibility in rams. Wholecrop maize (265 DM g/kg) was ensiled for 90 days in $210 \mathrm{~L}$ drums with no additive, or with LL or LB. After three months, the drums were opened and the silage was sampled for fermentation characteristics. Diets were produced by mixing the whole-crop maize silage with lucerne hay $(90: 10)$ on an "as fed" basis, and a digestibility study was conducted using five South African Mutton Merino rams (37.2 $\pm 2.2 \mathrm{~kg}$ live weight) per treatment. Inoculating maize silage with LL and LB reduced ammonia nitrogen concentration, but did not affect silage $\mathrm{pH}$. The concentration of lactic acid was increased with LL compared to the other treatments. A higher concentration of acetic acid was obtained with LB inoculation compared to the other treatments. The aerobic stability of the silage was improved with LB while it was reduced with LL inoculation, as indicated by a higher $\mathrm{CO}_{2}$ production than the latter. The intake and digestibility of dry matter, organic matter, crude protein and fibre were improved by inoculation. Furthermore, inoculations resulted in improved nitrogen retention. It was concluded that the inoculants improved silage fermentation and diet digestibility. Inoculation with LB improved aerobic stability and LL inoculation reduced it.
\end{abstract}

Keywords: Alfalfa, lucerne, aerobic stability, Lactococcus lactis, Lactobacillus buchneri

\# Corresponding author: Dnkosi@arc.agric.za

\section{Introduction}

The ensiling of crops has been a preferential method in maintaining the energy nutrient content of crops, ensuring a good nutritional value when used as feed (Vervaeren et al., 2010). By ensiling, lactic acid bacteria (LAB) consume the sugar compounds (water-soluble carbohydrates, WSC) in the crop and lower the $\mathrm{pH}$, eventually inhibiting further degradation by other bacteria (McDonald et al., 1991). Whole-crop maize (Zea mays L.) is one of the most ensiled crops in the world, due to its ease of cultivation, high production rate, low buffering capacity and high concentration of WSC (McDonald et al., 2002).

To ensure that there is enough $\mathrm{LAB}$ for the efficient fermentation of forages during ensiling, bacterial inoculants comprising mainly LAB are used. These micro-organisms have been reported to increase lactic acid concentration and cause a rapid decline of $\mathrm{pH}$ in silage (Weinberg \& Muck, 1996). In a summary of studies conducted between 1990 and 1995, Muck \& Kung (1997) reported that homolactic LAB inoculation of whole-crop maize improved dry matter (DM) recovery and animal performance by 2 to $3 \%$ and 3 to $5 \%$, respectively. However, inoculants that contain mainly homofermentative LAB have often reduced the aerobic stability of silage because of the insufficient production of volatile fatty acids (VFA) (Rust et al., 1989; Weinberg et al., 1993; Muck \& Kung, 1997). Consequently, hetero-fermentative LAB was developed to improve aerobic stability, as the conversion of lactic acid into acetic acid prevents rapid aerobic degradation of nutrients after silage opening (Driehuis et al., 2001, Danner et al., 2002).

It has been reported that maize silage is one of the major forage sources in the diets of ruminants in South Africa (Cilliers et al., 1998; Meeske \& Basson, 1998). According to Schmidt \& Kung (2010), maize 
silage is very sensitive to aerobic deterioration, because of its high concentration of substrates such as starch and organic acids, which are utilized by undesirable micro-organisms. In addition, the warm climate in South Africa could render maize silage to be susceptible to aerobic deterioration, because aerobic yeasts are most active at 20 to $30{ }^{\circ} \mathrm{C}$ (Ashbell et al., 2002). Bacterial inoculants, such as Lactococcus lactis (LL), a homofermentative LAB inoculant (McDonald et al., 1991, Siren et al., 2009) and Lactobacillus buchneri (LB), a heterofermentative LAB inoculant (Weinberg \& Muck, 1996, Holzer et al., 2003) have been widely used for the preservation of herbages. Our previous research with maize silage (Nkosi et al., 2009) and potato hash silage (Nkosi et al., 2010; Nkosi \& Meeske, 2010) showed improved aerobic stability of silage with LB inoculation. Contreras-Govea et al. (2011) reported a reduced non-protein nitrogen (NPN) concentration in ensiled alfalfa with LL inoculation, and Ozkose et al. (2009) reported reduced fibre fractions in ensiled wheat straw with LL inoculation compared to the control. However, the latter studies were conducted under laboratory-scale conditions and the aerobic stability of the silage and the effects of the inoculated silage on animal performance were not determined. Research on the ensiling of whole-crop maize with L. lactis in South Africa is limited, and the effects of inoculants may vary from one place to another (Schmidt \& Kung, 2010). The objective of this study was therefore to determine the effects of two inoculants, LB and LL, on the fermentation characteristics of whole-crop maize, and on nutrient digestibility in rams.

\section{Materials and Methods}

Maize (hybrid Senkuil, Sensako obtained in Brits, South Africa) was planted during November 2008, in Irene, South Africa (longitude $28^{\circ} 13^{\prime} \mathrm{S}$ : latitude $25^{\circ} 55^{\circ} \mathrm{E}$, altitude $1524 \mathrm{~m}$ ) and harvested during midFebruary 2009 with a Feraboli 945 forage harvester (Fondata Nel, Cremona, Italy) adjusted to achieve a 10 $\mathrm{mm}$ theoretical chop length. The inoculants, Lactobacillus buchneri CCM 1819 and Lactococcus lactis NCIMB 30117 (Chr. Hansen, 10-12 Borge Alle, Horsholm, Denmark), were applied at a rate of 2 L/t of freshly chopped maize ( $2 \mathrm{~g}$ of inoculant was dissolved in $2 \mathrm{~L}$ water $4 \mathrm{~h}$ before application). In order to obtain at least $1.0 \times 10^{5} \mathrm{CFU} / \mathrm{g} \mathrm{LAB}$ per fresh maize before ensiling, the suspensions were plated immediately on de Man, Rogosa and Sharpe agar (Oxoid CM0361, Unipath, Basingstoke, UK) and analysed for LAB populations following the ISO (1998) procedure. To compensate for the water that was added to the treated silage, the control treatment was sprayed with $2 \mathrm{~L}$ of distilled water over a ton of fresh material to keep it at the same level of moisture as the treated silages. Three representative samples of the chopped maize were taken before ensiling to determine the chemical composition. The treatments were compacted $(968 \pm 23.5$ $\left.\mathrm{kg} / \mathrm{m}^{3}\right)$ by trampling it in $210 \mathrm{~L}$ drums $(5$ drums/treatment) which were lined with a double layer of polyethylene bags, equipped with clamps and weighted down with $20 \mathrm{~kg}$ concrete pavers. The drums were individually sealed after expelling the air, and stored at $22-25^{\circ} \mathrm{C}$. After three months of ensiling, the five drums were opened during the three-week digestibility study as the silage was needed. Representative silage samples were collected from each drum to determine the chemical composition and fermentation characteristics. The aerobic stability of the silage was determined immediately after the drums were opened by exposing a representative silage sample to air for $5 \mathrm{~d}\left(30^{\circ} \mathrm{C}\right)$ and the $\mathrm{CO}_{2}$ production was determined as described by Ashbell et al. (1991).

A representative $40 \mathrm{~g}$ silage sample was taken from each drum to determine the fermentation characteristics. The $40 \mathrm{~g}$ silage sample $(\mathrm{n}=5)$ was mixed with $360 \mathrm{~mL}$ of distilled water in a stomacher bag, homogenized for 4 min and the $\mathrm{pH}$ was determined immediately with a $\mathrm{pH}$ meter (Thermo Orion Model 525, Thermo Fisher Scientific, Waltham, MA, USA). The sample was then left at $10^{\circ} \mathrm{C}$ for $24 \mathrm{~h}$ (Suzuki \& Lund, 1980), homogenized for 4 min and filtered through a Whatman No. 4 filter paper (G.I.C. Scientific, Midrand, South Africa). The filtrate was used to determine WSC, VFAs, lactic acid (LA) and ammonia-N $\left(\mathrm{NH}_{3}-\mathrm{N}\right)$ concentrations. The WSC was determined by the phenol-sulphuric acid method according to Dubois et al. (1956) and the LA was determined by the colorimetric method of Barker \& Summerson (1941) as modified by Pryce (1969). The VFAs were determined with a Varian 3300 FID Detector gas chromatograph (Varian Associates, Inc., Palo Alto, CA, USA) according to the procedure of Suzuki \& Lund (1980). The $\mathrm{NH}_{3}-\mathrm{N}$ was determined by distillation, using a Buchi 342 apparatus and a Metrohm 655 Dosimat with an E526 titrator according to AOAC (ID 941.04, 1990). This is based on the method of Pearson \& Muslemuddin (1968) for determining volatile nitrogen $(\mathrm{N})$.

The DM of the silage was determined by drying the samples at $60{ }^{\circ} \mathrm{C}$ until a constant mass was achieved, and was corrected for the loss of volatiles by using the equation of Porter \& Murray (2001). After 
being dried, the samples were ground through a 1-mm screen (Wiley mill, Standard Model 3, Arthur H. Thomas Co., Philadelphia, PA) for chemical analyses. The acid detergent fibre (ADF) was determined, using a Fibertec System 1010 (FOSS Analytical AB, Sweden) and boiling samples in an acidic solution followed by filtration (ID 973.18, AOAC, 1990). The amylase-treated neutral detergent fibre (aNDF) was determined by using amylase and sodium sulphite (Van Soest et al., 1991). Separate samples were used for ADF and aNDF analysis and both included residual ash. Crude protein (ID 968.06), organic matter (OM) (ID 942.05) and ether extract (EE) (ID 963.15) were determined according to the procedure of AOAC (1990), while the gross energy (GE) was determined by bomb calorimeter (MS-1000 modular calorimeter, Energy Instrumentation, 135 Knoppieslaagte, Centurion, South Africa).

Diets were produced weekly by mixing maize silage with chopped lucerne hay $(960 \mathrm{~g} \mathrm{DM} / \mathrm{kg}, 865 \mathrm{~g}$ $\mathrm{OM} / \mathrm{kg} \mathrm{DM}, 182 \mathrm{~g} \mathrm{CP} / \mathrm{kg} \mathrm{DM}, 568 \mathrm{~g}$ aNDF/ $\mathrm{kg} \mathrm{DM}, 378 \mathrm{~g} \mathrm{ADF} / \mathrm{kg} \mathrm{DM}$ ) at a ratio of $9: 1$ (as is basis). One drum of silage per treatment was used during the first week and two drums of silage per treatment per week during the second and the third week of the digestion study, respectively. A representative silage sample of each diet was collected weekly $(n=3)$ and analysed for DM, OM, CP, GE, EE and fibre (ADF and aNDF). The diets were offered individually ad libitum to 15 South African Mutton Merino rams $(37.2 \pm 2.21 \mathrm{~kg}$ live weight) with five replicates per diet. The rams had ad libitum access to fresh water at all times and feed intake was measured daily. The rams were adapted to the experimental diets and metabolism crates for 14 days, followed by a seven day urine and faecal collection period. The rams were fitted with leather harnesses and canvass bags attached to the back of each ram three days before the digestion trial started. Urine was collected in $10 \mathrm{~L}$ buckets that contained $100 \mathrm{~mL}$ of $10 \%$ sulphuric acid with a funnel fitted under the cages. Daily outputs of faeces and urine were recorded, subsampled and kept frozen at $-20{ }^{\circ} \mathrm{C}$. Faeces and urine accumulated for the 7-day period were pooled and subsamples were collected for laboratory analyses. The rams were treated according to the regulations of the Animal Ethics Committee of the ARC-API (2008).

Data on the effects of the treatments on fermentation, chemical composition and aerobic stability of silage was analysed in a completely randomized design by ANOVA using Genstat (2005). Differences in treatment means were compared with the least significant difference (LSD) and significance declared at the $0.05 \%$ probability level. Data was fitted to the model: $Y_{i j}=\mu+t_{i}+\varepsilon_{i j}$ where: $Y_{i j}$ is the individual observations of the $\mathrm{i}$-th treatment and the $\mathrm{j}$-th replicate, $\mu$ is the general effect, $t_{\mathrm{i}}$ is the effect of the $\mathrm{i}$-th treatment and $\varepsilon_{\mathrm{ij}}$ is the random variation or residual error.

Effects of treatments (inoculants) on nutrient digestibility in rams were analysed with the model:

$Y_{i j}=\mu+t_{i}+\beta_{j}+\varepsilon_{i j}$ where: $Y_{i j}$ is the individual observations of the $i$-th treatment and the $j$-th replicate, $\mu$ is the general effect, $t_{i}$ is the effect of the $\mathrm{i}$-th treatment, $\beta_{\mathrm{j}}$ is the effect of the $\mathrm{j}$-th replicate, $\varepsilon_{\mathrm{ij}}$ is the random variation or experimental error.

\section{Results and Discussions}

Bacterial inoculants are used during ensiling to accelerate the fermentation process and result in a faster reduction in silage $\mathrm{pH}$ (McDonald et al., 2002). Results on the fermentation and chemical composition of the whole-crop maize silage are shown in Table 1. The chemical composition of freshly chopped wholecrop maize indicates that it was harvested at an early stage of maturity, as indicated by its DM of $265 \mathrm{~g} / \mathrm{kg}$ (Filya, 2004) and similar to that of our previous study (Nkosi et al., 2009).

A pH range of $3.7-4.2$ is generally considered to be beneficial for whole-crop maize preservation (Kung \& Shaver, 2001) and in our study the $\mathrm{pH}$ was less than 3.9, which is indicative of well-preserved silage. However, bacterial inoculation did not influence the $\mathrm{pH}$ of the maize silage, which is in agreement with previous studies (Phillip \& Fellner, 1992; Kung et al., 1993; Wardynski et al., 1993; Muck, 2010) but in contrast to others (Fellner et al., 2001; Nkosi et al., 2009) who reported a reduced pH with inoculation of maize silage. The lack of response to inoculated maize is expected as the $\mathrm{pH}$ in maize silage often drops to 4 within the first 48 hours of ensiling, leaving very little room for improvement in the rate of preservation (Meeske, 2005). Moreover, differences in types of inoculants, components of the maize plant ensiled, as well as the moisture content of the crop, could partly explain variability in the fermentation quality of inoculated maize (Fellner et al., 2001).

Water-soluble carbohydrates are regarded as essential substrates for the growth of LAB for proper fermentation (McDonald et al., 1991), and low levels may restrict LAB growth. The WSC concentration of our whole-crop maize, prior to ensiling, was within the typical range of $80-300 \mathrm{~g} / \mathrm{kg}$ DM for maize silage (Pitt, 1990). However, after 90 days of ensiling, the inoculated silages had lower $(P<0.05)$ residual WSC 
concentrations compared to the control, indicating that more WSC was utilized by LAB in the inoculated silages.

High quality silage is likely to be achieved when lactic acid is the predominant acid produced, as it is the most efficient fermentation acid, and reduces silage $\mathrm{pH}$ more efficiently than other fermentation products (McDonald et al., 2002). It has been reported that when forages are inoculated with homofermentative LAB inoculants before ensiling, the resulting silage usually has a lower $\mathrm{pH}$ and a higher concentration of lactic acid, but lower concentrations of acetic acid, butyric acid and $\mathrm{NH}_{3}-\mathrm{N}$ compared to heterofermentative LAB inoculants (Muck, 2010). As expected, the inoculation of LL in maize at ensiling increased $(P<0.05)$ the concentrations of lactic acid compared to the other treatments. Furthermore, there are some studies (e.g. Filya, 2003) that reported a reduced concentration of lactic acid with L. buchneri inoculation in maize silage compared to the control. In contrast, Mari et al. (2009) and Nkosi et al. (2009) did not find a reduced lactic acid concentration in L. buchneri inoculated maize silage compared to the control. The latter studies agreed with results of the present study because the concentration of lactic acid was similar between L. buchneri and the control treatments.

The inoculation of L. buchneri resulted in an increased $(P<0.05)$ concentration of acetic acid compared to the other treatments. This is consistent with other researchers (Ranjit et al., 2002; Nkosi et al., 2009) who reported increased acetic acid with L. buchneri inoculation. Furthermore, a relationship between acetic acid and aerobic stability was proposed by Danner et al. (2003) who claimed that increasing acetic acid concentrations inhibited spoilage by micro-organisms, thereby promoting aerobic stability.

Table 1 Effects of inoculants on the fermentation characteristics and chemical composition of whole-maize silage after 90 days of ensiling $(n=5)$

\begin{tabular}{|c|c|c|c|c|c|c|}
\hline & \multirow{3}{*}{$\begin{array}{l}\text { Pre-ensiled } \\
\quad(\mathrm{n}=3)\end{array}$} & \multicolumn{3}{|c|}{ Silage } & \multirow{3}{*}{ SEM } & \multirow{3}{*}{$P$} \\
\hline & & \multicolumn{3}{|c|}{ Inoculant treatments } & & \\
\hline & & Control & LB & LL & & \\
\hline \multicolumn{7}{|c|}{ Fermentation characteristics } \\
\hline $\mathrm{DM}, \mathrm{g} / \mathrm{kg}$ & $265 \pm 1.24$ & $224^{\mathrm{b}}$ & $229^{\mathrm{a}}$ & $231^{\mathrm{a}}$ & 0.92 & 0.003 \\
\hline WSC, g/kg DM & $104.3 \pm 0.62$ & $25.3^{\mathrm{a}}$ & $21.5^{\mathrm{c}}$ & $23.1^{\mathrm{b}}$ & 0.27 & 0.002 \\
\hline $\mathrm{pH}$ & $6.11 \pm 0.104$ & 3.6 & 3.6 & 3.5 & 0.07 & 0.107 \\
\hline LA, g/kg DM & & $85.2^{\mathrm{b}}$ & $84.7^{\mathrm{b}}$ & $96.2^{\mathrm{a}}$ & 1.09 & 0.003 \\
\hline AA, g/kg DM & & $7.9^{\mathrm{b}}$ & $39.6^{\mathrm{a}}$ & $6.8^{\mathrm{c}}$ & 0.21 & 0.002 \\
\hline $\mathrm{PA}, \mathrm{g} / \mathrm{kg} \mathrm{DM}$ & & $0.18^{\mathrm{b}}$ & $0.32^{\mathrm{a}}$ & $0.0^{\mathrm{c}}$ & 0.02 & 0.002 \\
\hline BA, g/kg DM & & NF & $\mathrm{NF}$ & $\mathrm{NF}$ & & \\
\hline $\mathrm{NH}_{3}-\mathrm{N} \mathrm{g} / \mathrm{kg} \mathrm{TN}$ & & $10.96^{\mathrm{a}}$ & $9.20^{\mathrm{b}}$ & $7.22^{\mathrm{c}}$ & 0.012 & 0.001 \\
\hline $\mathrm{CO}_{2} \mathrm{~g} / \mathrm{kg} \mathrm{DM} *$ & & $19.87^{b}$ & $4.87^{\mathrm{c}}$ & $25.17^{\mathrm{a}}$ & 0.564 & 0.002 \\
\hline \multicolumn{7}{|l|}{ Chemical composition } \\
\hline $\mathrm{OM}$ g/kg DM & 944.3 & $938^{b}$ & $943^{\mathrm{a}}$ & $945^{\mathrm{a}}$ & 0.7 & 0.016 \\
\hline $\mathrm{CP} g / \mathrm{kg} \mathrm{DM}$ & 94.2 & $81.5^{\mathrm{c}}$ & $85.0^{\mathrm{b}}$ & $89.7^{\mathrm{a}}$ & 2.02 & 0.004 \\
\hline $\mathrm{EE} \mathrm{g} / \mathrm{kg} \mathrm{DM}$ & 24.3 & $28.7^{\mathrm{a}}$ & $20.4^{c}$ & $20.0^{\mathrm{b}}$ & 0.24 & 0.001 \\
\hline ADF g/kg DM & 244.1 & $251.4^{\mathrm{a}}$ & $217.1^{\mathrm{b}}$ & $220.5^{\mathrm{b}}$ & 1.43 & 0.001 \\
\hline aNDF $\mathrm{g} / \mathrm{kg}$ DM & 526.0 & $437.5^{\mathrm{a}}$ & $427.6^{b}$ & $391.5^{\mathrm{c}}$ & 2.13 & 0.001 \\
\hline
\end{tabular}

${ }^{\mathrm{a}-\mathrm{c}}$ Means with different superscripts within a row differ significantly $(P<0.05)$.

Inoculants: LL - Lactococcus lactis; LB - Lactobacillus buchneri.

DM - dry matter; WSC - water-soluble carbohydrates; LA - lactic acid; AA - acetic acid; PA - propionic acid; $\mathrm{BA}$ - butyric acid; $\mathrm{NH}_{3}-\mathrm{N}$ - ammonia-N; $\mathrm{TN}$ - total nitrogen; $\mathrm{NF}$ - not found; $\mathrm{CO}_{2}$ - carbon dioxide; OM - organic matter; CP - crude protein; EE - ether extract; ADF - acid detergent fibre; aNDF - neutral detergent fibre (amylase technique).

* $\mathrm{CO}_{2}$ produced after five days of aerobic exposure. 
Ammonia- $\mathrm{N}$ in silage reflects the degree of protein degradation, and extensive proteolysis adversely affects the utilization of $\mathrm{N}$ by ruminants (Wilkinson, 2005). Well-preserved silages should contain less than $100 \mathrm{~g} \mathrm{NH}_{3}-\mathrm{N} / \mathrm{kg}$ total $\mathrm{N}$ (McDonald et al., 2002). Our inoculated maize silage had $\mathrm{NH}_{3}-\mathrm{N}$ concentrations that were lower than this value, which is indicative of well-preserved silage. It has been reported that inoculation reduced proteolysis during ensiling and resulted in improved efficiency of silage protein utilization and reduced $\mathrm{N}$ losses (Charmley, 2001). According to McDonald et al. (1991), this effect arose as a result of the $\mathrm{pH}$ reduction with inoculation which inhibits protein degradation in silages. Although the $\mathrm{pH}$ was not affected by inoculation, $\mathrm{NH}_{3}-\mathrm{N}$ was reduced $(P<0.05)$ by inoculation in our study. No traces of butyric acid were obtained in this study.

The concentration of $\mathrm{CP}$ was higher $(P<0.05)$ in the inoculated silages compared to the control. This could be attributed to reduced proteolysis with inoculation compared to the control (McDonald et al., 2002). Furthermore, the fibre fractions (ADF and aNDF) of the silage were reduced $(P<0.05)$ with inoculation compared to the control. This supports other studies that reported a reduced fibre content with inoculation (Sanderson, 1993; Keady \& Steen, 1994; Ozkose et al., 2009). In contrast, some researchers (Faber et al., 1989; Phillip \& Fellner, 1992) did not observe a reduction in cell-wall fractions from inoculated silages compared to the control. This was attributed to the lower environmental temperature that inhibited hemicellulose degradation (Faber et al., 1989).

Aerobic stability of silage is of great importance because of the consequent losses of nutrients and $\mathrm{DM}$, and the potential development of moulds which have the potential to produce mycotoxins, that can pose health hazards to animals and humans (Driehuis \& Oude Elferink, 2000). Carbon dioxide is one of the indicators of aerobic stability in silage when exposed to air (McDonald et al., 1991) and an increase in $\mathrm{CO}_{2}$ concentration in the silage indicates aerobic deterioration (Ashbell et al., 1991). It has been reported that inoculation of homofermentative LAB inoculant in silage often reduces its aerobic stability because of insufficient production of VFAs (Rust et al., 1989; Weinberg et al., 1993; Muck \& Kung, 1997). However, inoculants containing L. buchneri have improved the aerobic stability of different silages (Driehuis et al., 2001; Weinberg et al., 2002; Kleinschmidt et al., 2005; Nkosi \& Meeske, 2010). This effect is attributed to the inhibitory effect of acetic acid produced by L. buchneri on the spoilage by fungi (Driehuis et al., 2001; Ranjit et al., 2002). Our results showed that inoculation with L. buchneri in whole-crop maize at ensiling reduced $(P<0.05)$ the production of $\mathrm{CO}_{2}$ when compared to the other treatments, which is indicative of improved aerobic stability with this inoculant. According to previous research (Driehuis et al., 2001; Nkosi et al., 2009) inoculating with L. buchneri typically results in acetic acid concentrations ranging from 36 to 50 $\mathrm{g} / \mathrm{kg} \mathrm{DM}$, suitable to control yeast during aerobic exposure of silage. Therefore the acetic acid concentration of $39 \mathrm{~g} / \mathrm{kg}$ DM in the L. buchneri treated maize silage in the present study was enough to control yeast. In contrast, Steidlova \& Kalac (2003) reported no improvement in the aerobic stability of maize silages inoculated with L. buchneri. The researchers cited this lack of response due to lower and similar amounts of acetic acid produced between the treatments (microsil, L. buchneri and L. plantarum), and heating occurred between the treatments. In the present study, the aerobic stability of whole-crop maize silage was reduced $(P<0.05)$ with LL inoculation, supporting other studies (e.g. Nkosi et al., 2010) that reported reduced aerobic stability of silage with a homofermentative LAB inoculation.

Propionic acid which has an important effect on the inhibition of yeasts, was increased $(P<0.05)$ with L. buchneri inoculation compared to the other treatments. This increase in propionic acid concentration in the L. buchneri inoculated silage can be explained by the conversion of LA to acetic acid and 1-2 propanediol (Oude Elferink et al., 2001) followed by the conversion of 1-2 propanediol to propionic acid and 1-propanal by L. diolovorans (Krooneman et al., 2002).

The addition of $100 \mathrm{~g} / \mathrm{kg}$ lucerne hay in all the treatments improved the nutritive value (e.g. DM, CP) of the diets (Table 2). However, the diets that contained the inoculated silage had a higher CP and lower fibre content (ADF and aNDF) compared to the diet that contained the control silage (Table 2). This might be due to the differences in the fermentation quality of the silages since a lower $\mathrm{NH}_{3}-\mathrm{N}$ concentration was obtained in the inoculated silages compared to the control, an indication that proteolysis was restricted by inoculation, consistent with other researchers (Rooke et al., 1988; Gordon, 1989).

In a review on the mode of action of silage inoculants, Weinberg \& Muck (1996) suggested that inoculants could enhance animal performance by altering rumen fermentation. Furthermore, some researchers attributed the enhanced animal performance by feeding inoculated silage to animals to 
Table 2 Chemical composition of experimental diets $(\mathrm{n}=3)$

\begin{tabular}{|c|c|c|c|c|c|}
\hline & \multicolumn{3}{|c|}{ Treatments diets } & \multirow{2}{*}{ SEM } & \multirow{2}{*}{$P$} \\
\hline & Control & LB & LL & & \\
\hline $\mathrm{DM} g / \mathrm{kg}$ & $301.0^{\mathrm{b}}$ & $310.0^{\mathrm{a}}$ & $311.7^{\mathrm{a}}$ & 0.694 & 0.001 \\
\hline $\mathrm{OM} \mathrm{g} / \mathrm{kg} \mathrm{DM}$ & $926.7^{\mathrm{b}}$ & $932.3^{\mathrm{a}}$ & $936.7^{\mathrm{a}}$ & 0.471 & 0.001 \\
\hline $\mathrm{CP}$ g/kg DM & $102.3^{\mathrm{c}}$ & $117.1^{\mathrm{b}}$ & $121.3^{\mathrm{a}}$ & 0.254 & 0.001 \\
\hline GE MJ/kg DM & $15.6^{\mathrm{b}}$ & $15.8^{\mathrm{b}}$ & $16.8^{\mathrm{a}}$ & 0.072 & 0.001 \\
\hline $\mathrm{EE}$ g/kg DM & $32.5^{\mathrm{a}}$ & $25.9^{\mathrm{c}}$ & $28.8^{\mathrm{b}}$ & 0.205 & 0.005 \\
\hline ADF $g / k g$ DM & $286^{\mathrm{a}}$ & $262^{\mathrm{b}}$ & $261^{\mathrm{b}}$ & 0.76 & 0.001 \\
\hline aNDF $\mathrm{g} / \mathrm{kg}$ DM & $476^{\mathrm{a}}$ & $465^{\mathrm{b}}$ & $462^{\mathrm{b}}$ & 0.58 & 0.005 \\
\hline
\end{tabular}

${ }^{\mathrm{a}-\mathrm{c}}$ Means with different superscripts in a row differ significantly $(P<0.05)$.

Inoculants: LL - Lactococcus lactis; LB - Lactobacillus buchneri.

$\mathrm{DM}$ - dry matter; OM - organic matter; CP - crude protein; GE - gross energy; EE - ether extract;

ADF - acid detergent fibre; aNDF - amylase-treated neutral detergent fibre.

Table 3 Effects of treatments on daily feed intake (g/d, on DM basis) and apparent digestibility $(\mathrm{g} / \mathrm{kg})$ of diets in sheep $(\mathrm{n}=5)$

\begin{tabular}{|c|c|c|c|c|c|}
\hline & \multicolumn{3}{|c|}{ Treatments diets } & \multirow{2}{*}{ SEM } & \multirow{2}{*}{$P$} \\
\hline & Control & LB & LL & & \\
\hline \multicolumn{6}{|c|}{ Feed intake g/d (DM basis) } \\
\hline DMI & $1043^{\mathrm{c}}$ & $1188^{\mathrm{b}}$ & $1259^{\mathrm{a}}$ & 10.8 & 0.001 \\
\hline OMI & $971^{\mathrm{c}}$ & $1107^{\mathrm{b}}$ & $1166^{\mathrm{a}}$ & 12.7 & 0.001 \\
\hline CPI & $106^{\mathrm{c}}$ & $139^{\mathrm{b}}$ & $152^{\mathrm{a}}$ & 3.1 & 0.001 \\
\hline GEI MJ/day & $16.7^{\mathrm{b}}$ & $19.2^{\mathrm{a}}$ & $19.8^{\mathrm{a}}$ & 0.187 & 0.001 \\
\hline EEI & 34.4 & 33.6 & 32.2 & 2.22 & 0.001 \\
\hline ADFI & $373^{\mathrm{a}}$ & $281^{\mathrm{b}}$ & $241^{\mathrm{b}}$ & 19.42 & 0.020 \\
\hline aNDFI & $540^{\mathrm{a}}$ & $478^{b}$ & $448^{\mathrm{b}}$ & 32.41 & 0.011 \\
\hline \multicolumn{6}{|c|}{ Apparent digestibility $(\mathrm{kg} / \mathrm{d})$} \\
\hline DMD & $766^{\mathrm{c}}$ & $778^{\mathrm{b}}$ & $831^{\mathrm{a}}$ & 0.03 & 0.001 \\
\hline OMD & $783^{\mathrm{c}}$ & $797^{\mathrm{b}}$ & $873^{\mathrm{a}}$ & 0.01 & 0.001 \\
\hline CPD & $801^{\mathrm{b}}$ & $809^{\mathrm{b}}$ & $875^{\mathrm{a}}$ & 0.01 & 0.002 \\
\hline $\mathrm{DE} \mathrm{MJ} / \mathrm{kg} \mathrm{DM}$ & $12.7^{\mathrm{c}}$ & $15.5^{\mathrm{b}}$ & $16.5^{\mathrm{a}}$ & 0.082 & 0.007 \\
\hline EED & $903^{\mathrm{a}}$ & $906^{\mathrm{a}}$ & $883^{\mathrm{b}}$ & 0.06 & 0.038 \\
\hline ADFD & $659^{\mathrm{b}}$ & $753^{\mathrm{a}}$ & $798^{\mathrm{a}}$ & 0.02 & 0.001 \\
\hline aNDFD & $639^{\mathrm{b}}$ & $755^{\mathrm{a}}$ & $758^{\mathrm{a}}$ & 0.01 & 0.001 \\
\hline
\end{tabular}

\footnotetext{
${ }^{\mathrm{a}-\mathrm{c}}$ Means with different letters in a row differ significantly $(P<0.05)$.

Inoculants: LL - Lactococcus lactis; LB - Lactobacillus buchneri.

DMI - dry matter intake; OMI - organic matter intake; CPI - crude protein intake; GEI - gross energy intake; EEI - ether extract intake; ADFI - acid detergent fibre intake; aNDFI - amylase treated neutral detergent fibre intake; DMD - dry matter digestibility; OMD - organic matter digestibility; CPD - crude protein digestibility; DE - digestible energy; EED - ether extract digestibility; ADFD - acid detergent fibre digestibility; aNDFD - amylase-treated neutral detergent fibre digestibility.
}

i) improved efficiency of energy utilization due to higher levels of propionate in the rumen caused by an inoculant (Keady \& Steen, 1994), and to ii) reduced ruminal deamination with inoculation (Sharp et al., 
1994). According to Kennedy (1990), the effect of an inoculant on animal performance may not be significant if the untreated silage is well preserved. When fed to rams (Table 3), the inoculated silage increased $(P<0.05)$ the intake of DM, OM, CP and GE compared to the control, which agrees with Rooke et al. (1988) and Rooke \& Kafilzadeh (1994) when inoculated silage was fed to sheep as the sole feed. In contrast, some work on maize silage (Rust et al., 1989; Wardynski et al., 1993) did not report an improved intake of DM with inoculation. Furthermore, Phillip \& Fellner (1992) reported improvements in aerobic stability of high moisture corn following bacterial inoculation, but observed no beneficial effects on the growth performance of steers.

It is further revealed in Table 3 that inoculation improved $(P<0.05)$ the digestibility of DM, OM, CP and the fibre fractions (ADF and aNDF). This is consistent with the work of other researchers (Gordon, 1989; Schaefer et al., 1989; Phillip et al., 1990; McAllister et al., 1998) who reported increased digestibility of DM in grass, alfalfa and corn silages with inoculation, but inconsistent with other studies that reported a lack of improvement in the digestibility of silage with inoculation (Wittenberg et al., 1983; Sanderson, 1993).

Inoculation of maize silage increased $(P<0.05) \mathrm{N}$ retention compared to the control (Table 4), which is consistent with other researchers (Luther, 1986; Okine et al., 2005; Nkosi et al., 2010). Rooke et al. (1988) attributed the improvements in $\mathrm{N}$ retention with inoculated silages to a reduction in the urinary excretion of $\mathrm{N}$. However, in the present study, increases in $\mathrm{N}$ retention appeared to be related to an improved $\mathrm{N}$ digestion as opposed to a reduction in urinary $\mathrm{N}$ excretion (McAllister et al., 1998). According to McDonald et al. (1991), inoculants have been shown to reduce proteolysis in silage, but this has not been shown to increase the amount of potentially degradable $\mathrm{N}$ available to the animal (Marshall et al., 1993). In the present study the differences in $\mathrm{N}$ digestion among silages could not be explained on the basis of ammonia levels in the silage, but may have been related to the improved aerobic stability of the silages (McAllister et al., 1998; Nkosi \& Meeske, 2010). In contrast, Fellner et al. (2001) reported that treatment differences in aerobic stability of high moisture ear corn did not account for the responses in growth performance of beef cattle.

Table 4 Effects of treatments on nitrogen $(\mathrm{N})$ intake $(\mathrm{g} / \mathrm{kg} \mathrm{DM})$, excretion and retention in sheep fed whole crop maize silage diet $(n=5)$

\begin{tabular}{|c|c|c|c|c|c|}
\hline & \multicolumn{3}{|c|}{ Treatment diets } & \multirow{2}{*}{ SEM } & \multirow{2}{*}{$P$} \\
\hline & Control & LB & LL & & \\
\hline NI, g/kg DM & $16.9^{\mathrm{b}}$ & $22.2^{\mathrm{b}}$ & $24.3^{\mathrm{a}}$ & 1.41 & 0.004 \\
\hline Faecal N, g/d & $4.8^{\mathrm{a}}$ & $4.5^{\mathrm{a}}$ & $3.4^{\mathrm{b}}$ & 0.25 & 0.004 \\
\hline $\mathrm{N}$ urine, $\mathrm{g} / \mathrm{d}$ & 5.2 & 5.4 & 5.3 & 0.62 & 0.054 \\
\hline TN excretion, $g / d$ & $10.0^{\mathrm{a}}$ & $9.9^{\mathrm{a}}$ & $8.7^{\mathrm{b}}$ & 0.33 & 0.001 \\
\hline $\mathrm{N}$ retention, $\mathrm{g} / \mathrm{d}$ & $6.9^{\mathrm{c}}$ & $12.3^{\mathrm{b}}$ & $15.6^{\mathrm{a}}$ & 1.17 & 0.001 \\
\hline $\mathrm{N}$ retention $(\% \mathrm{NI})$ & $46.0^{\mathrm{c}}$ & $55.5^{\mathrm{b}}$ & $64.2^{\mathrm{a}}$ & 1.08 & 0.001 \\
\hline
\end{tabular}

\footnotetext{
${ }^{\mathrm{a}-\mathrm{c}}$ Means with different letters in a row differ significantly $(P<0.05)$.

Inoculants: LL - Lactococcus lactis; LB - Lactobacillus buchneri.

NI - nitrogen intake; TN - total nitrogen.
}

\section{Conclusions}

The inoculant treatments had positive effects on the fermentation of maize silage and improved the intake, apparent digestibility and $\mathrm{N}$ retention of maize silage diets. Lactococcus lactis increased lactic acid and reduced the ammonia $\mathrm{N}$ content of maize silage. The aerobic stability of maize silage was reduced by L. lactis. Inoculation with $L$. buchneri increased the acetic acid and propionic acid content of maize silage, reduced $\mathrm{NH}_{3}-\mathrm{N}$ and improved aerobic stability. This study showed that bacterial inoculation of whole-crop maize during ensiling may improve the quality of maize silage. 


\section{References}

Animal Ethics Committee, 2008. Animal Ethics Committee of the ARC-Animal Production Institute (API), Irene, South Africa.

AOAC, 1990. Official Methods of Analysis. $15^{\text {th }}$ ed. Association of Official Analytical Chemists, Washington D.C., USA.

Ashbell, G., Weinberg, Z.G., Azriel, A., Hen, Y. \& Horev, B., 1991. A simple system to study the aerobic deterioration of silages. Can. Agric. Eng. 33, 391-393.

Ashbell, G., Weinberg, Z.G., Hen, Y. \& Filya, I., 2002. The effects of temperature on the aerobic stability of wheat and corn silages. J. Indust. Microbiol. Biotech. 28, 26-263.

Barker, S.B. \& Summerson, W.H., 1941. The colorimetric determination of lactic acid in biological material. J. Biol. Chem. 138, 535-54.

Charmley, E., 2001. Towards improved silage quality - a review. Can. J. Anim. Sci. 81, 157-168.

Cilliers, J.W., Cilliers, H.J. \& Nel, W.R.L., 1998. Maize silage, grain sorghum silage and forage sorghum silage in diets with different proportions of concentrate for the finishing of weaner lambs. Anim. Sci. 66, 189-196.

Contreras-Govea, F.E., Muck, R.E., Mertens, D.R. \& Weimer, P.J., 2011. Microbial inoculant effects on silage and in vitro ruminal fermentation, and microbial biomass estimation for alfalfa, bmr corn, and corn silages. Anim. Feed Sci. Technol. 163, 2-10.

Danner, H., Holzer, M., Maryhuber, E. \& Braun, R., 2003. Acetic acid increases stability of silage under aerobic conditions. Appl. Environ. Microbiol. 69, 562-567.

Driehuis, F. \& Oude Elferink, S.J.W.H., 2000. The impact of the quality of silage on animal health and food safety. A review. Vet. Q. 22, 212-216.

Driehuis, F., Oude Elferink, S.J.W.H. \& Van Wikselaar, P.G., 2001. Fermentation characteristics and aerobic stability of grass silage inoculated with Lactobacillus buchneri, with or without homofermentative lactic acid bacteria. Grass Forage Sci. 56, 330-343.

Dubois, M., Giles, K.A., Hamilton, J.K., Rebes, P.A. \& Smith, F., 1956. Colorimetric method for determination of sugars and related substances. Anal. Chem. 28, 350-356.

Faber, D.A., Linn, J.G. \& Otterby, D.E., 1989. Effect of a bacterial inoculant on the fermentation of high moisture shelled and ear corn. J. Dairy Sci. 72, 1234-1242.

Fellner, V., Phillip, L.E., Sebastian, S. \& Idziak, E.E., 2001. Effects of a bacterial inoculant and propionic acid on preservation of high moisture ear corn, and on rumen fermentation, digestion and growth performance of beef cattle. Can. J. Anim. Sci. 81, 273-280.

Filya, I., 2003. The effect of Lactobacillus buchneri with or without homofermentatitive lactic acid bacteria on the fermentation, aerobic stability and ruminal degradability of wheat, sorghum and maize silages. J. Appl. Microbiol. 95, 1080-1086.

Filya, I., 2004. Nutritive value and aerobic stability of whole crop maize silage harvested at four stages of maturity. Anim. Feed Sci. Technol. 116, 141-150.

Genstat For Windows ${ }^{\circledR}$ 2005. The Guide to Genstat Release 8. Ed. Payne, R.W., VSN International Ltd., Oxford, UK.

Gordon, H.K., 1989. An evaluation through lactating cows of a bacterial inoculant as an additive for grass silage. Grass Forage Sci. 44, 169-178.

Holzer, M., Mayrhuber, E., Danner, H. \& Braun, R., 2003. The role of Lactobacillus buchneri in forage preservation. Trends Biotechnol. 21 (6), 282-287.

ISO (International Organization for Standardization: 15214), 1998. Microbiology of food and animal feeding stuffs: Horizontal method for the enumeration of mesophilic lactic acid bacteria - Colony-count technique at 30 degrees $\mathrm{C}$.

Keady, T.W.J. \& Steen, W.J., 1994. Effects of treating low dry matter grass with a bacterial inoculant on the intake and performance of beef cattle and studies on its mode of action. Grass Forage Sci. 49, 438-446.

Kennedy, S.J., 1990. An evaluation of three bacterial inoculants and formic acid as additives for first harvest grass. Grass Forage Sci. 45, 281-288.

Kleinschmit, D.H.R., Schmidt, R.J. \& Kung Jr., L., 2005. The effects of various antifungal additives on the fermentation and aerobic stability of corn silage. J. Dairy Sci. 88, 2130-2139. 
Krooneman, J., Faber, F., Alderkamp, A.C., Oude Elferink, S.J.H.W., Driehuis, F., Cleenwerck, I., Swings, J., Gottschal, J.C. \& Van Canneyt, M., 2002. Lactobacillus diolivorans sp. nov., a 1,2 - propanedioldegrading bacterium isolated from aerobically stable maize silage. Int. J. Syst. Evolut. Microbiol. 52, 639-646.

Kung Jr., L. \& Shaver, R., 2001. Interpretation and use of silage fermentation analysis reports. University of Wisconsin, Madison, WI, USA. Focus on Forage 3 (13), 1-5.

Kung Jr., L., Chen, J.H., Kreck, E.M. \& Knutsen, K., 1993. Effect of microbial inoculants on the nutritive value of corn silage for lactating dairy cows. J. Dairy Sci. 76, 3763-3770.

Luther, R.M., 1986. Effect of microbial inoculation of whole plant corn silage on chemical characteristics, preservation and utilization by steers. J. Anim. Sci. 63, 1329-1336.

Mari, L.J., Schmidt, R.J., Nussio, L.G., Hallada, C.M. \& Kung Jr., L., 2009. An evaluation of the effectiveness of Lactobacillus buchneri 40788 to alter fermentation and improve the aerobic stability of corn silage in farm silos. J. Dairy Sci. 92, 1174-1176.

Marshall, S.A., Campbell, C.P. \& Buchanan-Smith, J.G., 1993. Proteolysis and rumen degradability of alfalfa silages preserved with a microbial inoculant, spent sulfite liquor, formic acid or formaldehyde. Can. J. Anim. Sci. 73, 559-570.

McAllister, T.A., Feniuk, R., Mir, Z., Selinger, L.B. \& Cheng, K.J., 1998. Inoculants for alfalfa silage: Effects on aerobic stability, digestibility and the growth performance of feedlot steers. Livest. Prod. Sci. 53, 171-181.

McDonald, P., Henderson, A.R. \& Heron, S.J.E., 1991. The Biochemistry of Silage. Chalcombe Publications, Marlow, Buckinghamshire, UK. pp. 109.

McDonald, P., Edwards, R.A., Greenhalgh, J.F.D. \& Morgan, C.A., 2002. Animal Nutrition. $6^{\text {th }}$ ed. Longman Scientific and Technical, Prentice Hall, New Jersey, USA.

Meeske, R., 2005. Silage inoculants: do they make a difference? S. Afr. J. Anim. Sci. 6, 49-55.

Meeske, R. \& Basson, H.M., 1998. The effect of lactic acid bacterial inoculant on maize silage. Anim. Feed Sci. Technol. 70, 239-247.

Muck, R.E., 2010. Silage additives and management issues. Proceedings of Idaho Alfalfa Forage Conference, Best Western Burley Inn, Burley, Idaho, USA. 16 - 17 February 2010. pp. 49-55.

Muck, R.E. \& Kung Jr., L., 1997. Effects of silage additives on ensiling. In: Silage: Field to feedbunk. NRAES-99, Ithaca, NY, USA. pp. 187-199.

Nkosi, B.D. \& Meeske, R., 2010. Effects of ensiling totally mixed potato hash ration with or without a heterofermentative bacterial inoculant on silage fermentation, aerobic stability, growth performance and digestibility in lambs. Anim. Feed Sci. Technol. 161, 38-48.

Nkosi, B.D., Meeske, R., Palic, D., Langa, T., Leeuw, K-J. \& Groenewald, I.B., 2009. Effects of ensiling whole crop maize with bacterial inoculants on the fermentation, aerobic stability, and growth performance of lambs. Anim. Feed Sci. Technol. 154, 193-203.

Nkosi, B.D., Meeske, R., Van der Merwe, H.J. \& Groenewald, I.B., 2010. Effects of homofermentative and heterofermentative bacterial silage inoculants on potato hash silage fermentation and digestibility in rams. Anim. Feed Sci. Technol. 157, 195-200.

Okine, A., Hanada, M., Aibibula, Y. \& Okamoto, M., 2005. Ensiling of potato pulp with or without bacterial inoculants and its effect on fermentation quality, nutrient composition and nutritive value. Anim. Feed Sci. Technol. 121, 329-343.

Oude Elferink, S.J.W.H., Krooneman, J., Gottschal, J.C., Spoelstra, S.F., Faber, F. \& Driehuis, F., 2001. Anaerobic conversion of lactic acid to acetic acid and 1,2-propanediol by Lactobacillus buchneri. Appl. Environ. Microbiol. 67, 125-132.

Ozkose, E., Akyol, I., Kar, B., Comlekcioglu, U. \& Ekinci, M.S., 2009. Expression of fungal cellulose gene in Lactococcus lactis to construct novel recombinant silage inoculants. Folia Microbiol. 54, 335-342.

Pearson, D. \& Muslemuddin, M., 1968. The accurate determination of volatile nitrogen in meat and fish. J. Assoc. Publ. Anal. 6, 117-123.

Pitt, R.E., 1990. Silage and hay preservation. Northeast Regional Agricultural Engineering Service (NRAES), Bulletin No. 5. Ithaca, New York, USA.

Phillip, L.E. \& Fellner, V., 1992. Effects of bacterial inoculation of high moisture ear corn on its aerobic stability, digestion and utilization for growth by beef steers. J. Anim. Sci. 70, 3178-3187. 
Phillip, L.E., Underhill, L. \& Garino, H., 1990. Effects of treating lurcene with an inoculum of lactic acid bacteria or formic acid upon chemical changes during fermentation, and upon the nutritive value of the silage for lambs. Grass Forage Sci. 45, 337-344.

Porter, M.G. \& Murray, R.S., 2001. The volatility of components of grass silage on oven drying and the inter-relationship between dry matter content estimated by different analytical methods. Grass Forage Sci. 56, 405-411.

Pryce, J.D., 1969. Modification of the Barker \& Summerson method for the determination of lactic acid. Analyst 94, 1151-1152.

Ranjit, N.K., Taylor, C.C. \& Kung Jr., L., 2002. Effect of Lactobacillus buchneri 40788 on the fermentation, aerobic stability and nutritive value of maize silage. Grass Forage Sci. 57, 73-81.

Rooke, J.A., Maya, F.M., Amold, J.A. \& Armstrong, D.G., 1988. The chemical composition and nutritive value of grass silages prepared with no additive or with the application of additives containing either lactobacillus plantarum or formic acid. Grass Forage Sci. 43, 87-102.

Rooke, J.A. \& Kafilzadeh, F., 1994. The effect upon fermentation and nutritive value of silages produced after treatment by three different inoculants of lactic acid bacteria applied alone or in combination. Grass Forage Sci. 49, 324-333.

Rust, S.R., Kim, H.S. \& Enders, G.L., 1989. Effects of a microbial inoculant on fermentation characteristics and nutritional value of corn silage. J. Prod. Agric. 3, 235-241.

Sanderson, M.A., 1993. Aerobic stability and in vitro fibre digestibility of microbially inoculated corn and sorghum silages. J. Anim. Sci. 71, 505-514.

Schaefer, D., Brotz, P.G., Arp, S.C. \& Cook, D.K., 1989. Inoculation of corn silage and high moisture corn with lactic acid bacteria and its effect on subsequent fermentations and on feedlot performance of beef steers. Anim. Feed Sci. Technol. 25, 23-38.

Schmidt, R.J. \& Kung Jr., L., 2010. The effects of Lactobacillus buchneri with or without a homolactic bacterium on the fermentation and aerobic stability of corn silages made at different locations. J. Dairy Sci. 93, 1616-1624.

Sharp, R., Hooper, P.G. \& Armstrong, D.G., 1994. The digestion of grass silages produced using inoculants of lactic acid bacteria. Grass Forage Sci. 49, 42-53.

Siren, N., Salonen, K., Leisola, M. \& Nyyssola, A., 2009. A new salt inducible expression system for lactoccus lactis. J. Biochem. Engng. 48, 132-135.

Steidlova, S. \& Kalac, P., 2003. The effects of using lactic acid bacteria inoculants in maize silage on the formation of biogenic amines. Arch. Anim. Nutr. 57 (5), 359-368.

Suzuki, M. \& Lund, C.W., 1980. Improved gas liquid chromatography for simultaneous determination of volatile fatty acids and lactic acid in silage. J. Agric. Food Chem. 28, 1040-1041.

Van Soest, P.J., Robertson, J.B. \& Lewis, B.A., 1991. Methods of dietary fiber, neutral detergent fiber, and non-starch polysaccharides in relation to animal nutrition. J. Dairy Sci. 74, 3583-3597.

Vervaeren, H., Hostyn, K., Ghekiere, G. \& Willems, B., 2010. Biological ensilage additives as pre-treatment for maize to increase the biogas production. Renewable Energy 35, 2089-2093.

Wardynski, F.A., Rust, S.R. \& Yokoyama, M.T., 1993. Effect of microbial inoculation of high moisture corn on fermentation characteristics, aerobic stability, and cattle performance. J. Anim. Sci. 71, 2246-2252.

Weinberg, Z.G. \& Muck, R.E., 1996. New trends in development and use of inoculants for silage. FEMS Microbiol. Reviews, 19, 53-68.

Weinberg, Z.G., Ashbell, G., Hen, Y. \& Azriel, A., 1993. The effect of applying lactic acid bacteria on the aerobic stability of silages. J. Appl. Bacteriol. 75, 512-518.

Weinberg, Z.G., Ashbell, G., Hen, Y., Azrieli, A., Szakacs, G. \& Filya, I., 2002. Ensilling whole crop wheat and corn in large containers with Lactobacillus plantarum and Lactobacillus buchneri. J. Ind. Microbiol. Biotechnol. 28, 7-11.

Wilkinson, J.M., 2005. In: Silage. Part 6: Assessing silage quality. Chapter 19: Analysis and clinical assessment of silage. Ed. Wilkinson, J.M., Chalcombe Publications, UK. pp. 198-208.

Wittenberg, K.M., Ingalls, J.R. \& Devlin, T.J., 1983. The effect of lactobacteria inoculation on corn silage preservation and feeding value for growing beef animals and lambs. Can. J. Anim. Sci. 63, 917-924. 